\title{
George Francis Train and the Woman Suffrage Movement, 1867-70
}

\author{
PATRICIA G. HOLLAND
}

In the fall of 1867, when Susan B. Anthony and Elizabeth Cady Stanton arrived from New York in wide open Kansas to canvass for woman suffrage, they decided to take the advice of a friend in St. Louis and see if they could get that entrepreneurial dazzler George Francis Train to give them a boost. On October 2, the local committee wired him in Omaha, "Come to Kansas and stump the state for equal rights and female suffrage. The people want you. The women want you."1

Train wired back in his breezy way a week later: "Right, Truth, Justice is bound to win. Men made laws, disfranchising Idiots, Lunatics, Paupers, Minors, and added Women as junior partner in the firm. The wedge once inserted in Kansas we will populate the nation with three millions voting women. Shall be with you as soon as our Editorial Party have shot their Buffalo, and seen the Rocky Mountains. Nebraska already allows women to vote in School Committee. If women can rule monarchies they should vote in republics." Susan B. Anthony answered the same day from Lawrence: "God bless you. Begin at Leavenworth Monday, Oct. 21st. Yes with your help we shall triumph."2

And so began Stanton's and Anthony's association with a man whose jam-packed life reflects the riproaring side of nineteenth-century America. In 1867 George Francis Train was a man of 38, tall and handsome, getting rich developing real estate in Omaha. Born March 14, 1829, in Boston and orphaned

${ }^{1}$ George Francis Train, The Great Epigram Campaign of Kansas; Championship of Women; The Revolution (Leavenworth, Kansas: Prescott \& Hume, 1867), p. 5.

2 Ibid., pp. 5-6. 
at the age of 4 during a yellow fever epidemic in New Orleans, he was raised by his grandparents in Waltham, Massachusetts, and went to work early for his father's cousin Enoch Train, who ran packets to Liverpool. At 21, the young Train went to Liverpool to manage the business there. He shortly after formed his own company and in 1853 headed with his wife to the gold rush town of Melbourne, Australia, where he was shipping agent, merchant, and insurance man and became involved in building the port facilities, all the while acting as a correspondent of the Boston Post. He also described his travels back to the United States via Asia and the Middle East in articles for the New York Herald. As a journalist, he was predicting by the end of 1856 the next year's panic and proposing, among other solutions, a railway to California and the annexation of Cuba. He himself chose to help develop the Atlantic and Great Western Railroad, soon part of the Erie line. He then went to Liverpool and London in 1860 and 1861 and built the first street railways there.

In 1862 he came home and began working with the Union Pacific Railroad on their expansion westward from the Missouri River. For their firm, he suggested the title Credit Mobilier, taken from a French company that in 1852 had devised new methods of financing the construction of public works; whether the American Credit Mobilier also adopted the French financing techniques is less clear. The author of an 1881 study of the Credit Mobilier and the scandal created by the granting of stock to congressmen in return for their political influence called the name a "woeful mistake" for being foreign and described Train as "excitable and visionary to the point of insanity." 3 Nevertheless, it was Train who, in the initial stages of the Union Pacific's drive to the west, in 1863 and 1864, did the legwork in lowa and Nebraska arranging for the rights-of-way. Through the Credit Foncier, whose name he also borrowed from a French firm, he worked on the real estate side of the railroad expansion. The government gave the railroad company land rights the width of 40 miles on either side of its corridor and

${ }^{3}$ Rowland Hazard, The Credit Mobilier of America (Providence, Rhode Island, 1881), p. 17. 


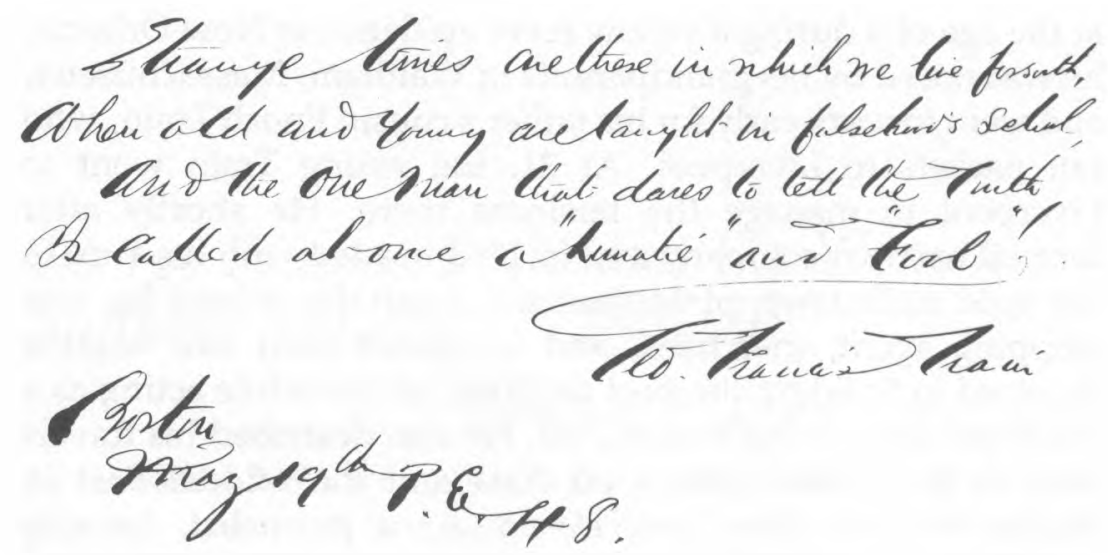

An autograph quotation signed by George Francis Train.

allowed it to sell off the lands to settlers and developers. Train invested in five hundred lots in Omaha and made enough money to buy a villa in Newport, Rhode Island. 4

When he came to Kansas for the woman suffrage cause, he and Susan B. Anthony, nine years his senior, stumped the state steadily for the last two weeks before the November election while Elizabeth Cady Stanton made another circuit in the company of a former governor. Two propositions were on the ballot, one to remove the word male from the state constitution and the other to remove the word white, or, in other words, to enfranchise women and to enfranchise Black men. Those supporting Black male suffrage, chiefly Republicans, tended to be sympathetic to woman suffrage but feared jeopardizing their main cause by supporting the secondary issue. Finding well-known men from the east to support either effort had proved impossible and hence the decision to seek Train's help.

Beginning in Leavenworth, Train and Anthony went to Lawrence, Olathe, Paola, Ottawa, Mound City, Fort Scott, Humboldt, Leroy, Burlington, Emporia, Junction City, Manhattan, Wyandotte, Topeka, and back to Leavenworth for

${ }^{4}$ Basic biographical facts about Train may be found in the Dictionary of American Biography. 
election day on November $5 .{ }^{5}$ At the end of the canvass Train compiled the newspaper reports of the tour, added his own comments, and in Leavenworth published the assemblage in a pamphlet, which gives a vivid sense of the tour. ${ }^{6}$ They spoke at a town a day, sometimes two. Anthony, with years of fastpaced canvassing experience behind her, arranged for renting the halls and advance publicity. Train would speak first, warming up the crowd, then let Anthony go on while he sat at the back and had something to eat. He stayed at the town hotel, if there was one, while she usually drew on the hospitality of a local supporter. Once they lost the path for their carriage, not arriving till 11:00 p.m., but they went on anyway and drew a good crowd. Their rapport was good. Later, when Anthony was describing their two-week journey to an audience in Buffalo, New York, she turned to Train next to her on the platform and asked him if he had ever counted the miles traveled on the tour. "We were together, Miss Anthony," he replied. "It did not seem long to me." The audience laughed and cheered. ${ }^{7}$

Anthony and Stanton credited Train with swaying the Democrats to woman suffrage. Train explicitly opposed enfranchising Black men, holding to a principle of educated suffrage. "Woman first, and negro last, is my programme; yet I am willing that intelligence should be the test, although some men have more brains in their hands than others in their heads. (Laughter.) Emmert's Resolution, introduced into your Legislature last year, disenfranchising, after July 4, 1870, all of age who can not read the American Constitution, the State Constitution, and the Bible, in the language in which he was educated (applause), expresses my views." 8 While Stanton and Anthony

${ }^{5}$ Ida Husted Harper, Life and Work of Susan B. Anthony (Indianapolis, Indiana: Hollenbeck, 1898), 1: 288-90; Train, Epigram Campaign, pp. 28-54.

${ }^{6}$ Epigram Campaign.

${ }^{7}$ Clipping from Buffalo Express, December 2, 1867, in Susan B. Anthony Scrapbook 2, Library of Congress, Rare Books Division.

${ }^{8}$ Quoted from a debate in Ottawa, Kansas, from an uncited source, presumably a newspaper account, in Elizabeth Cady Stanton, Susan B. Anthony, Matilda Joslyn Gage, History of Woman Suffrage, Vol. II, 1861-1876 (New York: Fowler \& Wells, 1882; repr. Arno Press, 1969) (hereafter cited as 
themselves supported removal of both male and white from the Kansas constitution, they too worked only against male.

On election day, the effort failed. Even so Anthony was exultant, for nearly a third of the voters, of course male and white only, supported woman suffrage. Two days after the election, she wrote to her friend Olympia Brown, the Universalist minister, who had worked on the Kansas campaign earlier that summer.

Leavenworth Nov. 7th 1867

\section{Dear Olympia,}

Never was so grand a success-never was defeat so glorious a victory-woman though probably lost-runs vastly ahead of negro-Miami Co. goes against 500-Atchison 500-Wyandotte 500 -Shawnee 500-\& all others heard from on the line of Rail Road not far from even-but lost-Leavenworth City \& County alone for us thus far-the one \& only point Geo. Francis Train's work had time to organize \& act- But don't despair-we shall winthe day breaks - the eastern sky isred-Mr. Train consents to lecture for our treasury's benefit-all the way down to Boston \& back to Philadelphia-commencing the 20th in't--. . . If only Geo. F. Train could have lighted the fires you had prepared all over the state-we should have carried it overwhelmingly - But depend upon it-there is a wise destiny in our delay-it is not defeat - So let us hope \& work to the brighter day - 9

As it turned out, Black male suffrage received slightly more support than did woman suffrage, and no one could foresee that enfranchising women would take so long. Kansas waited until 1912, both Stanton and Anthony dead, to grant women full suffrage, and even then it was only the seventh state to do so. Not until 1920 were there enough states to ratify the federal amendment giving women the vote; Mississippi still has not,

HWS, 2), p. 245; the phrase about language was doubtless aimed at the German constituency.

${ }^{9}$ Autograph Letter Signed (hereafter abbreviated as ALS), Olympia Brown Papers, Schlesinger Library, Radcliffe College. 
though the issue is dutifully raised in its state legislature each year.

Even as many as thirty years later, Stanton and Anthony believed Train's participation had been worthwhile. "He appealed most effectively to the chivalry of the intelligent Irishmen, and the prejudices of the ignorant; conjuring them not to take the word 'white' out of their constitution unless they did the word 'male' also; not to lift the negroes above the heads of their own mothers, sisters, and daughters. The result was a respectable democratic vote in favor of woman suffrage."10 Elizabeth Cady Stanton recalled the man in her reminiscences. "Mr. Train was then in his prime-a large, fine-looking man, a gentleman in dress and manner, neither smoking, chewing, drinking, nor gormandizing. He was an effective speaker and actor, as one of his speeches, which he illustrated, imitating the poor wife at the washtub and the drunken husband reeling in, fully showed. He gave his audience charcoal sketches of everyday life rather than argument. He always pleased popular audiences, and even the most fastidious were amused with his caricatures."11

A Kansas suffragist, Helen Ekin Starrett, recollected that Train in 1867

was at the height of his prosperity and popularity, and in appearance, manners, and conversation, was a perfect, though somewhat unique specimen of a courtly, elegant gentleman. He was full of enthusiasm and confident he would be the next President. He drew immense and enthusiastic audiences everywhere, and was a special favorite with the laboring classes on account of the reforms he promised to bring about when he should be President. Well do I remember one poor woman, a frantic advocate of woman suffrage, who button-holed everybody who spoke a word against Train to beg them to desist; assuring them 'that he was the special instrument of Providence to gain for us the Irish vote. ${ }^{\prime 2}$

${ }^{10}$ HWS, 2:243.

${ }^{11}$ Eighty Years and More: Reminiscences 1815-1897 (London: T. Fisher Unwin, 1898; repr. New York: Schocken, 1971, ed. Gail Parker), p. 256.

12 HWS, 2:254-55. 
Certainly Train was an entertainer. With his dark curls and good looks, he was known for wearing a white vest and lavender kid gloves, for speaking off the cuff, making up jingles, repeating himself unabashedly, and talking at length and sometimes with little apparent relevance about himself and his exploits.

But audiences enjoyed him, he had their ear. The reports of his speeches show him full of claims about what he would do if he were president. In both 1864 and in 1872 he did in fact run, independent of any party support. Whether he was running simply in the tradition of those who want a public airing of their views, or whether he might not have had serious ambitions is difficult to say. But nowhere have I found evidence that Anthony or Stanton themselves thought that he was supporting their cause with a view to eventually gaining the female vote.

By canvassing together Anthony and Train earned one another's firm respect, and it was during this tour that he decided there ought to be a woman suffrage newspaper. As Susan B. Anthony recalled it, she and Train were riding to Junction City, Kansas, from Emporia, when he asked her why her cause had no paper. She explained there was no money, that wealthy supporters like Wendell Phillips were focusing on the federal amendment to the constitution to enfranchise Black men. Train said he would give her the money.

Doubtful, she was astounded to hear him suddenly announce during his lecture that evening that Susan B. Anthony was going to start a woman suffrage paper. "Its name is to be The Revolution; its motto 'Men, their rights, and nothing more; women, their rights, and nothing less.' This paper is to be a weekly, price \$2 per year; its editors, Elizabeth Cady Stanton and Parker Pillsbury; its proprietor, Susan B. Anthony. Let everybody subscribe for it!" That was the first she heard of it, but this was the origin of the paper that she and Stanton produced from 1868 to 1870 , and the motto was the one they used. ${ }^{13}$

${ }^{13}$ Harper, The Life and Work of Susan B. Anthony, 1:290. 

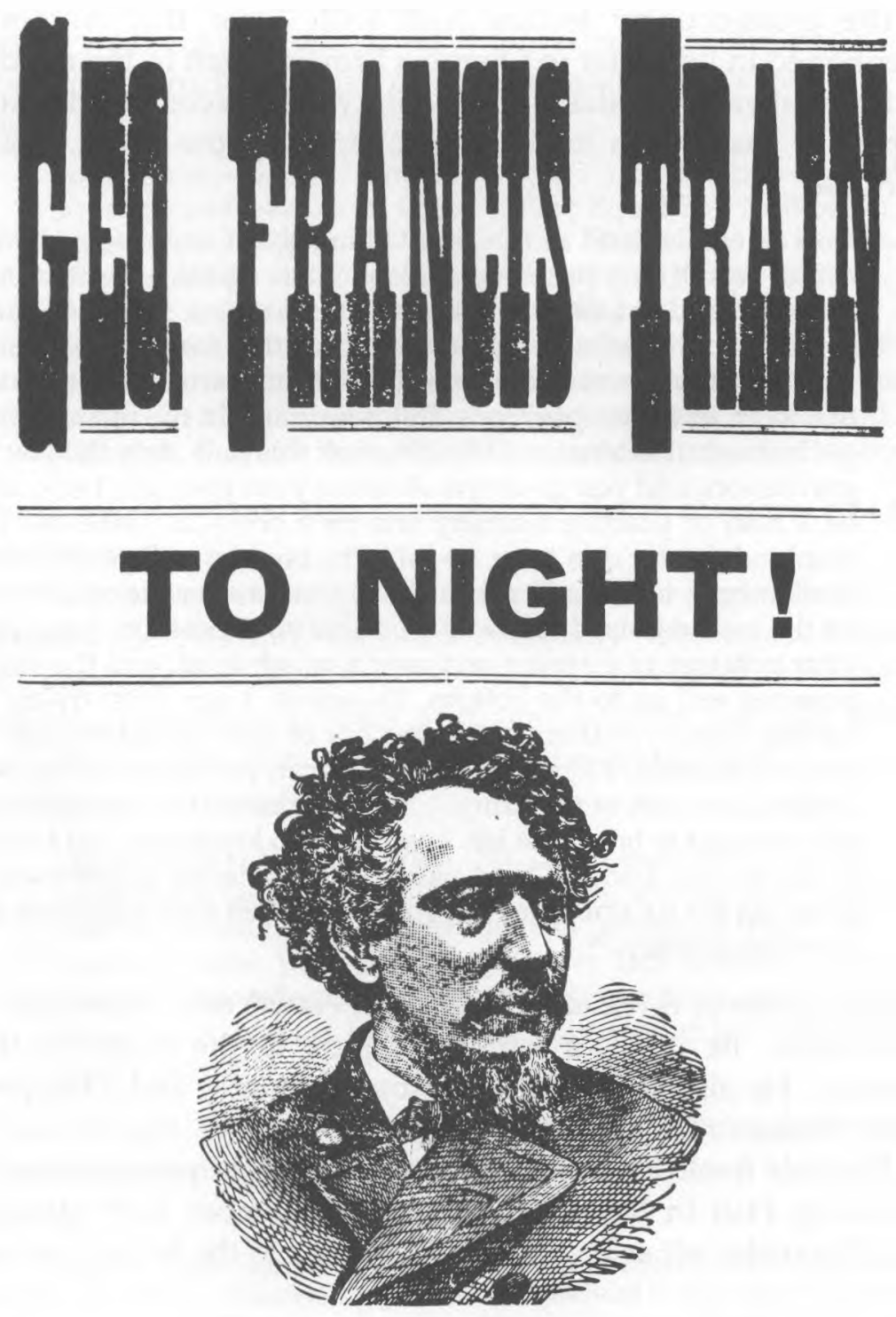

Under the Management of J. D. JONES. 
The cross-country lecture tour with Train that Anthony mentioned in her letter to Olympia Brown began in the middle of November in Omaha. Train's quirky style is conveyed in the report of his speech in St. Louis. Opening the event, Train declared

I am an egotist, and as I, before talking about women, shall talk about myself, suppose we explain what egotism is. It is not properly understood. I think that humility is a swindle-rank cowardice. I believe in egotism, and for this reason: Men can't get above their level in this world. There are certain natural laws that keep us in our positions. Put your hand in the fire and you get burned. It is a natural law. Step off this hall, defy the law of gravitation, and you go down. Assume your position, I say, and be a man or practice humility and be a coward. Strike out for mankind. Water don't run up hill. The big logs will get over the smaller ones in the mill pond, the big rocks over the small ones on the macadamized highway. Assume your position, I say. Put your potatoes in a spring cart over a rough road, and the small potatoes will go to the bottom. Therefore, I say, I am trying to elevate man by making an egotist out of him. Moral courage is not purchasable. Physical courage you can purchase for thirteen dollars, a month in the army. . . . I have made the introductory remarks just to break the ice. I want you to know me, and I want to know you. For it is hard work for these ladies to commence breaking the ice until they get votes, and then they will break ice over the country. ${ }^{14}$

In the course of three talks in Buffalo, New York, at the end of November, he urged a national capitol in the center of the country. He also advocated greenback currency and a temperance president. ${ }^{15}$

The tour finally ended with a Saturday night presentation in Steinway Hall in New York City on December 14. ${ }^{16}$ Stanton told Train she felt as if she were "fastened to the tail of a comet

${ }^{14}$ Newspaper report of speech of November 20, 1867, cited to St. Louis Democrat, n.d. [November 21, 1867], in Susan B. Anthony Scrapbook 2, Library of Congress, Rare Books Division.

${ }^{15}$ Buffalo Express, December 2, 1867, as cited above, note 7.

${ }^{16}$ Newspaper reports from the New York World, New York Herald, and Sunday Mercury (New York), all December 15, 1867, in Susan B. Anthony Scrapbook 2, Library of Congress, Rare Books Division. 
whisking 10,000 miles through the air." ${ }^{17}$ But they immediately began working on getting out the first issue of the paper. Its stationery proclaimed its principles, and Train's hand is in them.

In Religion-Nature, not Dogma; . . . In Politics-Educated Suffrage, irrespective of Color or Sex; Equal Pay to Women for equal Work; Dignity of Labor with Reduction of its Hours; Abolition of all standing Armies and all party Despotisms; . . . a new Commercial and Financial Policy. . . . . Gold, like our Cotton and Corn for sale. Greenbacks for money. Foreign Manufacturers Prohibited. Open doors to Artisans and Immigrants. . . W Wall Street emancipated from Bank of England, or American Cash for American Bills. . . More organized Labor. ${ }^{18}$

On January 4,1868 , they brought out the first number of the Revolution.

The connection with Train, however, brought down on Stanton and Anthony the wrath of many abolitionist friends, old supporters of the woman's rights movement, because of Train's opposition to Black suffrage. Toward the end of the lecture tour, Stanton responded to the criticism of a Quaker abolitionist, Edwin Studwell.

We are speaking for Woman. Mr. Train is doing the same. . . . He lays his talents \& wealth at our feet, giving us a triumphal journey through the states, papers reporting three \& four columns. Now you must suppose we lack common sense to drop the only influential man in the nation who is ready to stand by our guns. No! no! I love the cause of woman too well to reject such a power. ${ }^{19}$

Even though Train himself moved on to other endeavors as soon as he had initiated the paper, the wrath over his involve-

${ }^{17}$ Elizabeth Cady Stanton (hereafter ECS) to Elizabeth Smith Miller, December 28, 1867, in Elizabeth Cady Stanton As Revealed in Her Letters, Diary and Reminiscences, ed. Theodore Stanton, Harriot Stanton Blatch (New York: Harper \& Bros., 1922; repr. Arno Press, 1969), 2:118-19.

${ }^{18}$ See stationery used in letter of Susan B. Anthony to Olympia Brown, January 1, 1868, Olympia Brown Papers, Schlesinger Library, Radcliffe College.

${ }^{19}$ ECS to Edwin A. Studwell, November 30, 1867, ALS, Elizabeth Cady Stanton Papers, Vassar College; Studwell, born in 1837, was at this time publisher of a monthly journal, Friend. 
ment did not abate. In an early issue of the Revolution Stanton and Anthony printed an attack from William Lloyd Garrison.

January 4th [1868]

Dear Miss Anthony:

In all friendliness, and with the highest regard for the Woman's Rights movement, I cannot refrain from expressing my regret and astonishment that you and Mrs. Stanton should have taken such leave of good sense, and departed so far from true self-respect, as to be travelling companions and associate lecturers with that crack-brained harlequin and semi-lunatic, George Francis Train! . . . The colored people and their advocates have not a more abusive assailant before him, to whom he delights to ring the changes upon the 'nigger,' 'nigger,' ad nauseam. He is as destitute of principle as he is of sense, and is fast gravitating toward a lunatic asylum. He may be of use in drawing an audience; but so would a kangaroo, a gorilla, or a hippopotamus. It seems you are looking to the Democratic party, and not to the Republican, to give success politically to your movement! I should as soon think of looking to the Great Adversary to espouse the cause of righteousness. The Democratic party is the 'anti-nigger' party, and composed of all that is vile and brutal on the land with very little that is decent and commendable. ${ }^{20}$

The editors had already answered this kind of criticism in an early issue of the Revolution.

Since turning our faces eastward from Kansas we have been asked many times why we affiliated with the Democrats there, and why Mr. Train was on our platform. Mr. Train is there for the same reason that when invited by the 'Women's Suffrage Association' of St. Louis, he went to Kansas, because he believes in the enfranchisement of woman, not as a sentimental theory, a mere Utopia for smooth speech and golden age, but a practical idea, to be pushed and realized to-day. Mr. Train is a business man, builds houses, hotels, railroads, cities and accomplishes whatever he undertakes.... Though many of the leading minds of this country have advocated woman's enfranchisement for the last twenty years, it has been more as an intellectual

${ }^{20}$ Revolution, January 29, 1868; also in Letters of William Lloyd Garrison, Volume VI: To Rouse the Slumbering Land 1868-1879, eds. Walter M. Merrill and Louis Ruchames (Cambridge, Massachusetts: Belknap Press of Harvard University Press, 1981), pp. 29-30. 
theory than a fact of life, hence none of our many friends were ready to help in the practical work of the last few months, neither in Kansas or the Constitutional Convention of New York. So far from giving us a helping hand, Republicans and Abolitionists, by their false philosophy - that the safety of the nation demand ignorance rather than education at the pollshave paralized [sic] the women themselves.

The editorial went on to detail the support Stanton and Anthony had received from Democrats in Congress, noting that when the great Republican abolitionist Charles Sumner presented a woman suffrage petition to Congress he added the comment that he considered it "most inopportune." 21

To the Boston abolitionist Thomas Wentworth Higginson, Stanton wrote a personal letter.

I know we have shocked our old friends who were half asleep on the woman question with new life, just waking from slumber they are cross, can't see clearly where we are going, but time will show that Miss Anthony \& myself are neither idiots nor lunatics.... The position of such men as Garrison, Phillips, Sumner in their treatment of our question today proves that we must not trust any of you. All these men have pushed us aside for years saying "this is the negro's hour" now when we turn from them \& find help in other quarters, turn up the whites of their eyes! \& cry out the Cause. Now let me ask. Suppose George Francis Train had devoted his time \& money for three months to the negro as he has to the woman would not the abolitionists on all sides be ready to eulogize \& accept him, of course they would. Do they ignore everyone who is false to woman? by no means. Why ask us to ignore everyone who is false to the negro, though Mr. T. is not, when black men on the stump \& in their conventions repudiate woman. No! my dear friend we are right in our present position. We demand suffrage for all the citizens of the republic in the Reconstruction. I would not talk of negroes or women, but citizens. 22

Train had sailed for Europe on the eighth of January with his Union Pacific colleague Thomas C. Durant, leaving his friend and co-underwriter David Melliss of the New York World in

${ }^{21}$ Revolution, January 15, 1868.

22 ALS, January 13, 1868, Galatea Collection, Department of Rare Books and Manuscripts, Boston Public Library; printed in variant form in Elizabeth Cady Stanton As Revealed in Her Letters, Diary and Reminiscences, 2:120-21. 
charge of the financial pages of the Revolution. By extraordinary bad luck, he was detained by the British police when the ship arrived in Ireland on January 17, 1868, for carrying pro-Fenian literature, and then arrested. On February 26 he wrote from prison, "I shall join W[illiam]. L[loyd]. G[arrison]. and shall say drop Train. . ." $23 \mathrm{He}$ feared he was becoming a liability to the cause.

Stanton and Anthony did not repudiate him. They continued publishing his letters, mailed from the Battersea prison outside Dublin where he spent ten months, and the wrath Train excited did not abate. The following year at a New York equal rights convention, the movement divided into two separate organizations, the National Woman Suffrage Association, headed by Stanton and Anthony, and the American Woman Suffrage Association, based in Boston and headed by Lucy Stone and her husband Henry Blackwell. The split lasted for 20 years, the bitterness evident on both sides. And Train's name recurred even long past the time he had any connection with the cause.

He finally came back from Ireland early in 1869, and according to Susan B. Anthony's notes in the Revolution decided not to write for the paper, devoting himself to a busy lecture tour instead. He went to Promontory Point, Utah, to celebrate the meeting of the two transcontinental railroads on May 10, 1869, and then went on the road lecturing. But he continued support of the paper.

On January 1, 1870, Anthony thanked him.

Jan. 1st, 1870

Dear Mr. Train,

As I am looking over documents this New Year's day accumulated during my frequent and long absences from my office-I find this Order on the N.Y. World you so generously sent me. I return it to you - not that I don't want the $\$ 2,650.00-$ but that you, having returned to the City, may yourself collect the bill and have the added pleasure of handing me the Greenbacks.

As I look back over the two years since we met in Kansassince I saw you take those immense audiences of Irishmen all opposed to woman's voting-and time after time make every

${ }^{23}$ Revolution, March 19, 1868. 
man of them vote aye before you left-since the 9,070 votes of Kansas-since the tour of meetings all the way from Omaha to Boston and back to New York-since the starting of The Revolution-since your ten months in a British Bastile-since your twelve months lectures almost every night-I was wondering if for once you have ever let an audience go until you had made them vote for woman suffrage?

For every word you have spoken - for every vote you have taken - for every dollar you have given - and more than all for the increase of respect for and faith in myself with which you have inspired me-my soul blesses you, as does the Good Father and all his Angels-

With not one, but many a happy New Year Gratefully Yours, Susan B. Anthony ${ }^{24}$

Train's life at this time became remarkably hectic. In 1870 he decided to make a quick trip around the world, and while in Marseille fell into an adventure with the Communards which landed him in a jail in Lyons. As Train related the story, it took the combined efforts of the Dumas pere (an old acquaintance) and Leon Gambetta to get him out. ${ }^{25}$ Even with this interlude, his trip around the world still took only 80 days, and Train believed it was the basis of Jules Verne's tale published in 1873.

In 1872 he campaigned for president, and at the end of the year he publicly defended Victoria Woodhull's right to print her views about sex and for his troubles spent four months in the Tombs. The district attorney ordered him tried for insanity, but several "experts" found him a monomaniac but not insane, and the jury declared him sane. ${ }^{26}$ After that, he assigned his assets to his wife, and lived apparently apart from her in New York. He repeated his around-the-world trip in 1890 and again in 1892, setting a 60-day record. He lived in a crowded room in a New York hotel, and according to one report, used to hold Sunday "services" in Union Square of what he called the Church of the Laughing Jackass. In 1902, at the age of 73, he

${ }^{24}$ ALS, Manton Marble Papers, Manuscript Division, Library of Congress.

${ }^{25}$ My Life in Many States and Foreign Lands (New York: D. Appleton, 1902), pp. 302-13.

${ }^{26}$ See the report of the case in Clark Bell, Speech . . . upon the Inquiry as to the Sanity or Insanity of George Francis Train (New York: Russell Bros., 1873). 
dictated his memoirs, which contain fond tributes to his three children, and on January 18, 1904, died peacefully in his room, his daughter by his side.

I first discovered this extraordinary man when I became interested in the lives of Susan B. Anthony and Elizabeth Cady Stanton some years ago and since then have wanted to write about him. He was a man of energy and a charming kind of eccentricity, who inspired in people respect, affection, amazement, great amusement, and sometimes considerable alarm. How to evaluate this strange life? The question raises another, how to know that life? This is not to say no biography exists; I recommend two book-length sources, Train's own autobiography, My Life in Many States and Foreign Lands, published in 1902, shortly before he died, and Willis Thorton's The Nine Lives of Citizen Train published in 1948. ${ }^{27}$ But both these accounts, one based strictly on the author's elderly reminiscences, the other with a fine bibliography but lacking any description of the research conducted, and neither documented, present challenges to the person trying to find out the facts. Indeed, how would one go about verifying the variety of events of his life, some quite bizarre, in locations all over the world? And on what basis does one assess a person of his influence who shows signs of craziness, if an inspired and often prescient kind?

Take, for example, the issue of his insanity. When Alice Stone Blackwell wrote the biography of her mother, Lucy Stone, who broke with Stanton and Anthony over Train's involvement in the equal rights cause, she painted a portrait of the man that supported her mother's views. She says he spent time "in a lunatic asylum as actually insane." As noted above, he was judged not insane and jailed, not hospitalized. She says he was "an object of general ridicule," and to illustrate the point notes he had nominated himself for president and campaigned. That is hardly in itself an act commanding "gen-

\footnotetext{
27 New York: Greenberg.
} 
eral ridicule." 28 When Train was tried for insanity in 1873 , his lawyer listed the evidence in favor of the charge, that Train believes (1) that he is the coming Dictator; (2) that Horace Greeley was poisoned; (3) that he (Train) formed the Credit Foncier, Credit Mobilier, Commune in France, the Internationale; (4) that he has "deliria de grandeur." The lawyer conceded points 1 and 2 but on points 3 and 4 reviewed Train's life to show there was no delusion. Referring to the original provocation for the arrest, Victoria Woodhull's public accusation that Henry Ward Beecher committed adultery with a parishioner and Train's sympathy with the view, the lawyer admitted that Train has "ultra hostile" views on the profession of clergymen, implying that such views do not constitute insanity. ${ }^{29}$ Considered today, the ideas Train advocated-greenback currency, shorter working hours (when the ten-hour day was still a controversial idea), organized labor, equal pay for women for equal work-do not seem particularly outlandish but rather simply progressive, and so, I would say, they were then. While his behavior was plainly unusual and doubtless verging on the bizarre, his ideas were ones that many more respectable people supported. And yet, a current article on Train is titled "George Francis Train: The Great American Humbug," another in the tradition of citationless studies. ${ }^{30}$

To take another example of the difficulty of assessing his life, Train in his memoirs made a number of claims about things he invented, claims that invite incredulity. Among other things, he says, he invented the coal chute for a coal cart, the eraser attached to a pencil, perforated stamps, and steps as a part of a carriage. ${ }^{31}$ On a trip to Oregon in 1869 , he says he noticed the immense numbers of salmon the Indians were catching and thought up the idea of canned salmon. ${ }^{32}$ That was on the same trip that while sailing up the Puget Sound he picked out the future terminus for the Northern Pacific Railway, the spot that

${ }^{28}$ Lucy Stone: Pioneer of Woman's Rights (Boston: Little, Brown, 1930), p. 209.

${ }^{29}$ Clark Bell, Speech . . . upon the Inquiry as to the Sanity or Insanity of George Francis Train, pp. 18-22, 38.

${ }^{30}$ Dennis B. Downey, Journal of Popular Culture 14, no. 2 (Fall 1980), 251-60.

${ }^{31}$ My Life, pp. 107-8.

32 Ibid., p. 298. 
would become Tacoma, Washington. ${ }^{33}$ If his claims are read carefully, he does not say he did more than express the idea, leaving open the likelihood that someone else put the idea into practice, but given Train's reputation for grandiosity a biographer would want to try to verify these claims.

The work needed to do so would be staggering. To take one of his more impressive and interesting claims to illustrate the challenge of verification, he says that while working in Boston in the 1840 s he realized the profitability of promoting Irish immigration. He arranged for the Irishmen he knew around the wharf to scatter information throughout Ireland about the United States and how to get there. He also thought of two ways to make passage cheap and convenient by devising the "prepaid passenger certificate" and the "small one-pound (English money) bill of exchange." He then advertised these in the Boston Pilot, the Catholic newspaper, over the signature, apparently legitimate, of the archbishop. ${ }^{34}$ These actions should be possible to confirm, but the researcher would need access to the primary sources of Irish history of the 1840s, Boston Catholic church and newspaper records of that time, and records for the shipping firm. To see further whether or not the devices he claimed to have invented were indeed new, these same kinds of records would need to be checked further back. And finally the researcher would want to ask whether or not these innovations, if so they were, did in fact dramatically increase Irish immigration.

The complexity of research would need repeating for all his other endeavors. In one case, that of his accomplishments in Australia, that work has been well done. The lengthy introduction that E. Daniel and Annette Potts wrote to their book $A$ Yankee Merchant in Goldrush Australia: The Letters of George Francis Train 1853-55 is a model of such research. They were able to compare his descriptions of Melbourne from other sources for the time as well as preparing the only documented account of his life. It was interesting to learn from their study that for the most part his accounts and descriptions could be confirmed.

33 Ibid., p. 299.

34 Ibid., pp. 77-78. 
They do note that a building he built and remembered as six stories high was described in a contemporary account as only two and a half stories, an error consistent with his inclination to exaggerate but not remarkably egregious. ${ }^{35}$

His exploits in Italy of 1857 or 1858 (his memoirs do not say exactly) during the revolutionary times, when he was supposedly called Citizen Train and hailed as a liberator, would require considerable checking against contemporary accounts. Similar work would be needed on the 1870 escapade in Marseille and Lyons, France. His trips to and stories about China, India, Turkey, and Russia would all need at least some background research.

The papers that Train once had are now apparently gone, destroyed, according to two biographies, in 1903 on the suspicion that they harbored smallpox germs. ${ }^{36}$ His letters thus have to be tracked down in the collections of his correspondents. The University of lowa has the largest assemblage of Train documents, its core a collection of the papers of his Union Pacific colleague, Thomas C. Durant. They convey Train's galloping style of working and writing and detail the work Train did in the mid 1860 s for the railroad; to evaluate the information requires a good knowledge of railroad history, particularly its financial aspects. A few Train letters are in the papers of Whitelaw Reid, of the New York Tribune, at the Library of Congress, and in those of George T. Holyoake, in the Cooperative Union Library, Manchester, England. Doubtless, many more could be found. The Revolution contains his letters from jail in Ireland as well as reports about him, and local newspapers for the many places he worked and lectured in would be likely to contain reports.

Given the difficulty of determining the facts of his life, and bearing in mind that the story just told of his encounter with Susan B. Anthony and Elizabeth Cady Stanton has not yet been verified as it ought to be, it is with some hesitation that I evaluate even this small part of his life, his connection with the

${ }^{35}$ (Melbourne: Heinemann, 1970), p. xvi; My Life, p. 132.

${ }^{36}$ Don C. Seitz, Uncommon Americans (Indianapolis, 1926), p. 182, as cited in Potts, p. xxx; Thornton, p. 301. 
two women, and the uproar it caused. Curiously, or perhaps understandably, he makes no mention of it whatever in his memoirs. That he was a Copperhead was the ultimate charge of Stanton's and Anthony's equal-rights cohorts. The charge stemmed from an incident in Boston in 1862 when Train went to a speech by Charles Sumner in favor of immediate emancipation of the slaves and got up on the platform to voice his disagreement. Though many in the crowd shouted their support, he was carted off to jail for disrupting the meeting; he was shortly released. ${ }^{37}$ Apart from his opposition to abolition and Black suffrage, there were his political affiliations. While he was never a major voice in the Democratic party, his appeal was to the Democrats, the party of immigrants and the working class, rather than the Republicans of the antislavery tradition.

Along with the liability of that affiliation was his personal manner. His self-proclaimed lack of education, his plain way of talking without literary or philosophical allusions, his jingles, his love of money and what it could buy, his lack of piety and religiosity-all these, combined with his fancy dress, marked him - for many - as offensively uncultured. His very popularity condemned him, and despite Stanton's claim that the Garrisonians would not be so critical if he had come out for their cause, I think they would still have found his manner embarrassing. Some felt he made a mockery of the suffrage cause simply by his presence, that it would not do to accompany something so important and solemn with jokes and purple kid gloves. In Alice Stone Blackwell's analysis, "The general public looked upon the idea of woman suffrage as ridiculous, and it was highly undesirable to associate it with anything really ridiculous like $\mathrm{Mr}$. Train and his presidential aspirations." 38 Possibly that was a reasonable view to take given the newness of the idea that women should have equal

${ }^{37}$ My Life, pp. 277-79; see also William Lloyd Garrison to Helen E. Garrison, October 9, 1862, in Letters of William Lloyd Garrison, Volume 5: Let the Oppressed Go Free, 1861-1867 (Cambridge, Massachusetts: Belknap Press of Harvard University Press, 1979), p. 120, and note p. 121.

${ }^{38}$ Lucy Stone, p. 209. 
rights with men, but I think it also betrays an insecurity about the validity of the idea.

Train's extravagant exuberance clearly fueled the resentment, a resentment that revealed a general kind of nervousness about Train's energy and voluptuous enjoyment of lifedespite his nondrinking, nonsmoking habits - his love of travel and exotic places, of big financial schemes, huge enterprises, famous people. Certainly, he had no attraction to the spare life that was customary to the many Quakers and liberal Unitarians who filled the ranks of the antislavery organizations. Indeed, it is an interesting insight into Stanton and especially Anthony that they both found him a delightful companion and never wavered in their support. While Stanton had grown up in a wealthy and rather loosely structured household in upstate New York, where her father was a judge in Johnstown, and always frankly enjoyed the good life when she had it; Anthony's upbringing was more in the Quaker manner, following her father's faith, and she never apparently desired wealth or relished luxury. Still, she had no reclusive tendencies, was a practical and sociable person, her down-to-earth friendliness a lifelong characteristic. And her energy was a match for Train's.

This flash that the man ignited lit up and exposed, I would say, a real difference in reform styles. While Stanton and Anthony are sometimes distinguished from their Garrisonian forebears and colleagues for advocating political reform rather than moral reform, there was a qualitative difference accompanying the ideological one. Far more so than Garrison and his colleagues, whose work took place largely from the 1830s through the 1850s and was confined for the most part to New England and New York, the younger Stanton and Anthony had by the mid 1860s a much wider geographical focus for their cause. Personally, they shared with many others of their time the excitement produced by the opening of the western lands to settlement. Both of Susan B. Anthony's brothers settled in Kansas during the John Brown days, two of Stanton's children and one of her sisters went to Iowa, and each at times seriously 
thought of going west herself. ${ }^{39}$ The trip to Kansas was the first of what would become many trips to western lands, sometimes together on campaigns and often separately on lecture tours. While the trips were often arduous, each seemed to enjoy them, to find them exciting in a way their work in the east was not. In part, the climate for women's rights was considerably more favorable in the west, but I think besides the more enthusiastic reception they might find, the boom spirit of the fast-growing west carried over to them. Maybe it was because Train met Anthony and Stanton in Kansas that they responded so well to one another, in a place that at the time seemed to offer both prosperity and the prospect of equality.

To link up with someone like Train, whose racist attitudes were so antithetical to the beliefs of supporters of women's rights, also reflects another aspect of Stanton's and Anthony's reform styles. Especially for Anthony, with her action-oriented attitude, and in the postwar years for Stanton, expediency was in order. Alliances were necessary, they felt, if support for woman suffrage was ever to be achieved, and it was not objectionable to accept support from those whose other political views might be intolerable. There is no sign that when Anthony and Stanton sought Train's help that they anticipated the protest his connection would cause, and though they never gave any indication of regret, in hindsight it was probably an unwise move. Stanton and Anthony at that point were impatient for success, full of enthusiasm, and in their impatience, they apparently did not develop a broader philosophy of human rights by which to govern their actions. In their strategy they thus became careless in considering the means to reach the end. Wanting results and not being careful about the means

\footnotetext{
${ }^{39}$ See, for example, ECS to her husband, Henry Brewster Stanton, written from Council Grove, Kansas, October 9, 1867, urging that they buy land there and settle; transcript in Elizabeth Cady Stanton Papers, Manuscript Division, Library of Congress. Anthony for a time owned land in Atchison, bought in her name for speculative purposes by her brother Daniel Read Anthony; he later went on to be mayor of Leavenworth, and his son Daniel R. Anthony, Jr. was a longtime congressman from the district.
} 
used for obtaining them was, of course, Train's lifelong characteristic as well, and he was fortunate not to suffer very much by the consequences. ${ }^{40}$

${ }^{40}$ I would like to thank Gail Malmgreen for reviewing a draft of this article and for our helpful discussions of the topic. 